\title{
DYNAMICS OF CONCATENATION BETWEEN CARDIAC OUTPUT AND INDICES OF ARTERIAL BLOOD PRESURE DURING GRADED EXERCISE STRESS IN ENDURANCE COHORT
}

\author{
Vilma Papievienė, Eugenijus Trinkūnas, Alfonsas Buliuolis, \\ Albinas Grūnovas, Jonas Poderys \\ Lithuanian Sports University, Kaunas, Lithuania
}

\begin{abstract}
Research background and hypothesis. Potential mechanisms through which muscle perfusion is altered during prolonged exercise are not fully understood. The methods applied in the analysis of human data are very important because many crucial variables are not directly measureble or even identifiable.

Research aim was to find out the peculiarities in concatenation between central and peripheral cardiovascular changes under conditions of increasing fatigue.

Research methods. Well-trained endurance runners underwent a $50 \mathrm{~W}$ increase in workload (bicycle ergometry) every 6 minutes and they exercised until inability to continue the task. Dynamics of concatenation between cardiac output and systolic arterial blood pressure (ABP), diastolic ABP and total peripheral resistance were assessed using a method based on matrix theory proposed by Lithuanian scientists.

Research results. The increase of cardiac output during exercising has the same tendency of stepwise increase of workload, but changes of systolic and diastolic ABP with accumulation of fatigue could be characterized as linear type dependent with the time of exercising. The concatenation between the changes in cardiac performance and behaviour of peripheral vasculature increased at onset of exercising and the decrease or loss of the concatenation led up to inability to continue exercising.

Discussion and conclusions. The importance of peripheral factors, i. e. decrease of diastolic blood pressure, reduction of total peripheral vascular resistance plays an increasingly significant role for cardiac output during continuous exercising. The concatenations between the changes of these indices and cardiac output increase and in the case of high-grade fatigue concatenations begin to decline.
\end{abstract}

Keywords: cardiac output, periferal vascular resistance, concatenation.

\section{INTRODUCTION}

$\mathrm{I}$ is well known that major portion of cardiac outputs during exercising is diverted to the working muscles but potential mechanisms through which muscle perfusion is altered during prolonged exercise are not fully understood (Saltin, 2007). The interplay of central and peripheral changes of cardiovascular indices is oriented to the same purporse, e. g. to supply the needed amount of blood to active musculature. Since interaction of various cardiovascular parameters reflect important aspects of the regulation of vital processes these interactions need to be understood (Batzel, Bachar, 2010). Mathematical formalism is one of the ways to research the complexity of biological systems (Davis et al., 2010). The methods applied for the analysis of human data are very important because many crucial variables are not directly measureable or even identifiable (Torrents, Balagué, 2006; Poderys et al., 2010; Latash et al., 2010; Pukènas et al., 2012). 
The new methodology for assessment of concatenation between biological procesess was developed by a group of Lithuanian scientists (Vainoras et al., 2008; Bikulčienè et al., 2009). This methodology is based on matrix theory. The aim of this research was to find out the peculiarities in concatenation between central and peripheral cardiovacaular changes under conditions of increasing fatigue.

\section{RESEARCH METHODS}

The participants of the study (well trained endurance runners, $\mathrm{n}=13$ ) spent 20 min seated and after registration of the base-line values of cardiovascular indices they underwent a $50 \mathrm{~W}$ increase in workload (bicycle ergometry) every 6 minutes and they exercised unless distressing cardiovascular symptoms supervened.

The values of cardiac output and arterial blood pressure (ABP) measurements were registered at the end of each minute of the workload. The cardiac output was measured with tetrapolar chest rheography (RPG2-02, Medtekhnika, Moscow, Russia), a convenient and non-interventional method based on the Kubicek procedure (Pushkar et al., 1977). A four-electrode impedance plethysmographic system was used for this purpose. Two band electrodes were placed around the base of the subject's neck, the third band electrode was placed around the thorax $2 \mathrm{~cm}$ below the xiphisternal joint, and the fourth band electrode was placed around the abdomen like a belt. The two outer electrodes were placed about $2 \mathrm{~cm}$ away from the inner electrodes. The upper neck and abdomen electrodes were excited with a constant $100 \mathrm{kHz}$ sinusoidal current, and the resultant voltage (impedance) changes that occurred in the cardiac cycles were monitored from the two inner electrodes. The stroke volume was calculated from the impedance change information using a formula that related impedance changes to volume changes in a conducting solid (Kubicek et al., 1966).

Indirect arterial blood pressure (ABP) measurements (systolic $-\mathrm{S}$ and diastolic $-\mathrm{D}$ ) were taken from the arm with a sphygmomanometer and standard-size arm cuff. Mean arterial blood pressure (MAP) was calculated: MAP $=\mathrm{D}+(\mathrm{S}-\mathrm{D}) / 3$ and total systemic peripheral resistance (TPR) was calculated by MAP / CO $\left(\mathrm{mmHg} \cdot \mathrm{minL}^{-1}\right)$.

Dynamics of concatenation of registered indices was assessed using a method based on matrix theory proposed by Lithuanian scientists (Vainoras et al., 2008; Bikulčienè et al., 2009). According to this method two synchronous time series $\left(\mathrm{x}_{\mathrm{n}}:=0,1,2, ..\right)$ and $\left(\mathrm{y}_{\mathrm{n}}:=0,1,2, ..\right)$, which represented the results of some measurements were structured and analysed by using the numerical characteristics of the second order matrix and the main components of it:

$$
A_{n}:=\left[\begin{array}{cc}
x_{n} & x_{n-1}-y_{n-1} \\
x_{n+1}-y_{n+1} & y_{n}
\end{array}\right]
$$

From the definitions of matrix characteristics, the discriminants of the matrix are of great interest:

$$
\begin{aligned}
\operatorname{disk} A_{n}= & \left(\left(x_{n}-y_{n}\right)^{2}+4\left(\left(x_{n-1}-y_{n-1}\right) .\right.\right. \\
& \left.\cdot\left(x_{n+1}-y_{n+1}\right)\right)
\end{aligned}
$$

The initial data for the analysis of concatenation between parameters were the normalized values of the registered parameters. The parameters were interpolated using cubic splines, and then the discriminants between all investigated relationships were defined. Then the discriminants of all investigated relationships were defined. If discriminants of matrices became close to zero, the matrices from idempotent became to nilpotent, i.e. concatenation came close to maximal and conversely.

\section{RESEARCH RESULTS}

Working capacity. The task for the participants of this study was to continue exercising as long as they can, i.e. till the inability to continue it. All the participants of the study were able to perform the workload up to $200 \mathrm{~W}$, and only one participant was able to continue the workload at the stage of $350 \mathrm{~W}$. So the averaged data presented in Figures at the stages of $250 \mathrm{~W}$ and $300 \mathrm{~W}$ contain descending number of cases.

Dynamics of cardiovascular indices. Figure 1 presents the dynamics of cardiac output during the incremental increase in workload. The initial values of cardiac output obtained with tetrapolar chest rheography before the exercising was $6.1 \pm 0.41 / \mathrm{min}$ and the highest values was observed during the last stages of workout ( $31.21 / \mathrm{min}$, averaged). The increase of cardiac output while performing the workload has the same tendency of stepwise increase with each higher stage. This tendency increased during the first stages of workout and weakened when exercising became subjectively hard, i.e. during the last stages of workout. 
Figure 2 presents the dynamics of systolic and diastolic blood pressure. The type of change of these indices was not the same as the changes of cardiac output. The type of increase in systolic and decrease of diastolic ABP was more close to the linear changes, i. e. dependent on the time of exercising. The difference between systolic and diastolic ABP (pulse pressure) was observed while the participant of the study performed the last stages of workout.

At the onset of exercising steep decrease of TPR was observed $\left(15.8 \pm 0.9 \mathrm{~mm} \mathrm{Hg} \cdot \mathrm{minL}^{-1}\right.$ - before workload and $10.5 \pm 1.0 \mathrm{mmHg} \cdot \mathrm{minL}^{-1}-$ at the end of the first minute of the workload). The decrease of TPR was observed till the end of exercising, i. e. the lowest values were registered while performing the last steps of the workload $(250 \mathrm{~W} ; 300 \mathrm{~W}$ and $350 \mathrm{~W})-2.8 \pm 0.3 \mathrm{~mm} \mathrm{Hg} \cdot \mathrm{minL}^{-1}$ (Figure 3 ).

Dynamics of concatenation between measured indices are presented in Figure 3. At the onset of exercising the values of discriminant had different dynamics. There were relatively small changes of the discriminant while calculating the dynamics of concatenation between cardiac output and systolic ABP (Figure 3 A). The increase of the discriminant from $0.65 \pm 0.02$ (base-lane) to $0.88 \pm 0.13$ (maximal values obtained during the workload) was significant $(\mathrm{p}<0.05)$. The decline
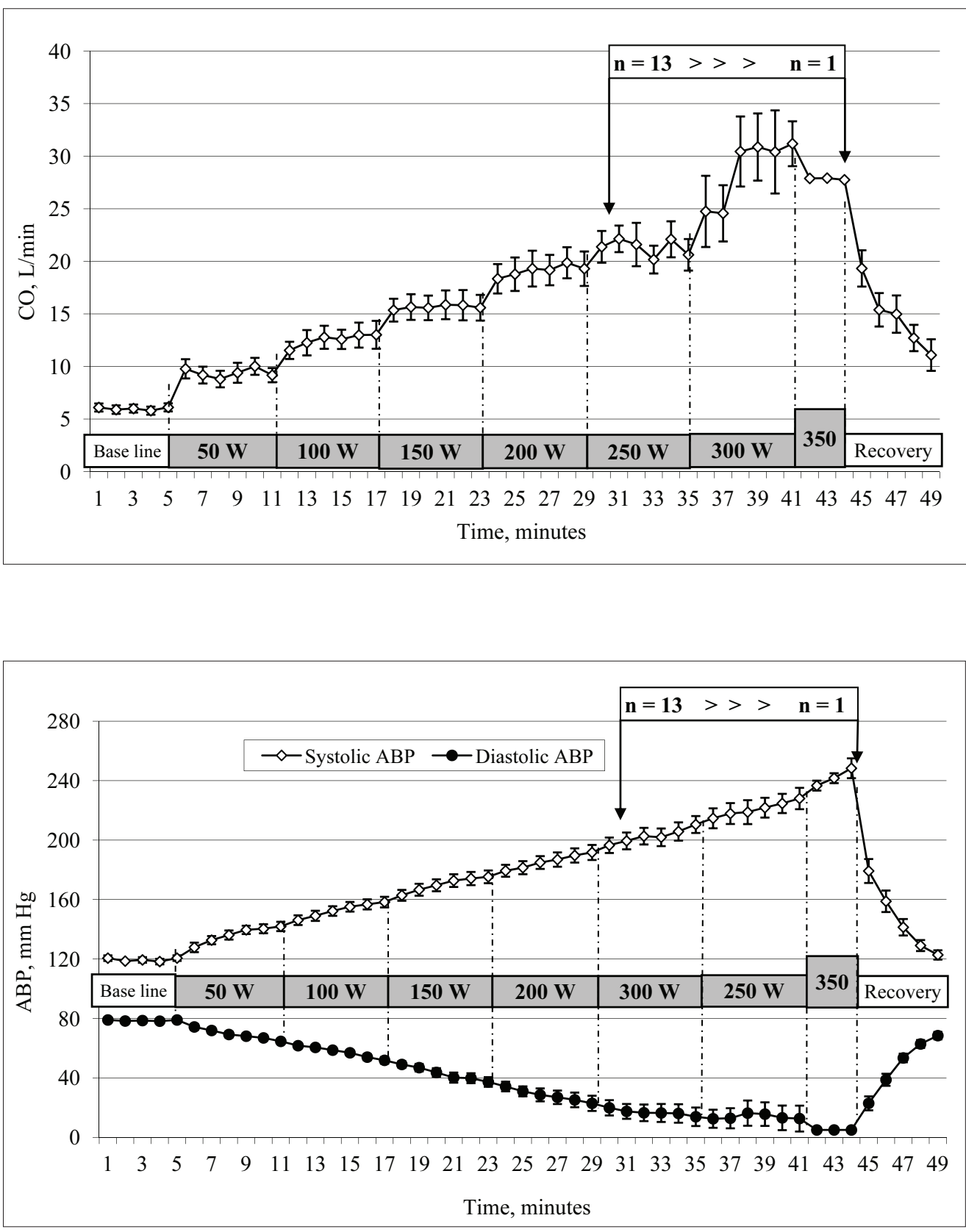

Figure 1. Cardiac output (CO) changes during incremental exercise stress

Note. $>>>-$ decreasing numbers of participants were able to perform the workload.

Figure 2. ABP changes during incremental exercise stress

Note. $>>>$ - decreasing numbers of participants were able to perform the workload. 
Figure 3. Total peripheral resistance (TPR) changes during incremental exercise stress

Note. $>>>-$ decreasing numbers of participants were able to perform the workload.

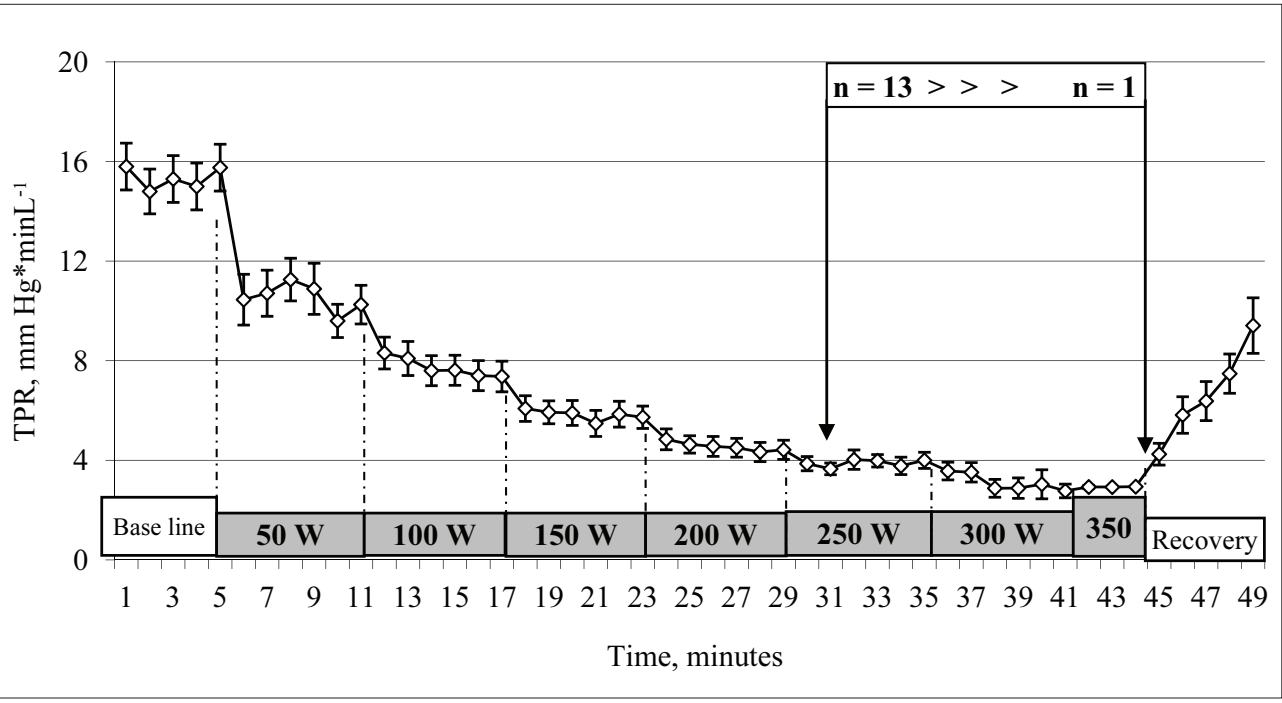

of the curve at the last stages of the workload in Figure 4A was related to the decreasing number of participants who were able to continue exercising at such intensive stages of the workload.

The initial values of the discriminant between cardiac output and diastolic ABP were $3.26 \pm 0.07$ and statistically significant decrease from the baseline $(p<0.05)$ was observed at onset of exercising. At each next minute of exercising as it is shown in Figure $4 \mathrm{~B}$ we observed further fall-dawn of the discriminant up to $0.13 \pm 0.06(\mathrm{p}<0.05)$. The increase of discriminant was observed while the exercising became subjectively hard and this steep increase was closely related (led up) with the inability to continue the performance of the workload.

Figure $4 \mathrm{C}$ demonstrates that reduction of total peripheral vascular resistance plays an increasingly significant role for cardiac output during exercising. The concatenation between the changes of these indices begin to decline at the onset of exercising and in the cases of high-grade fatigue, i. e. during the performance of the last stages of workload the steep increase of discriminant was observed.

\section{DISCUSSION}

It is well-known that major portion of cardiac outputs during exercising is diverted to the working muscles but potential mechanisms through which muscle perfusion is altered during prolonged exercise are not fully understood (Saltin, 2007). The aim of the research was to find out the peculiarities in concatenation between cardiac and peripheral cardiovascular changes under conditions of increasing fatigue. Since the analysis of the dynamics of short cardiovascular signal intervals reflects important vital processes, involving complex interactions of the regulatory processes (Batzel, Bachar, 2010), mathematical formalism is one of the ways to research the complexity of biological systems (Davis et al., 2010). A. L. Goldberger and his colleagues' publications (Goldberger, West, 1987; Goldberger et al., 1988) were one of the first publications in which HR variability was determined by non-linear analysis methods. Mathematical point of view in the analysis of biological systems in question - using mathematical analysis techniques - helps to reveal new features of the system, which can be approved or denied by empirical experiments (Demongeot et al., 2009).

Dynamics of concatenation between registered indices was assessed using a method based on matrix theory. The data obtained during such investigations have interpretation difficulties there are no standard methods developed where we could have a single interpretation. There is still no necessary experience in the application of this methodology and handling the obtained results. As the values of discriminants are very sensitive to initial data (Berškiene, 2009), the main attention in the analysis of changes should be pointed to the trends of the changes and to the moments at which the opposite changes start. Important point in physiological interpretation of these data is to take into account if discriminants of matrices become close to zero, then matrices from idempotent become nilpotent, i. e. concatenation comes close to maximal and conversely. 


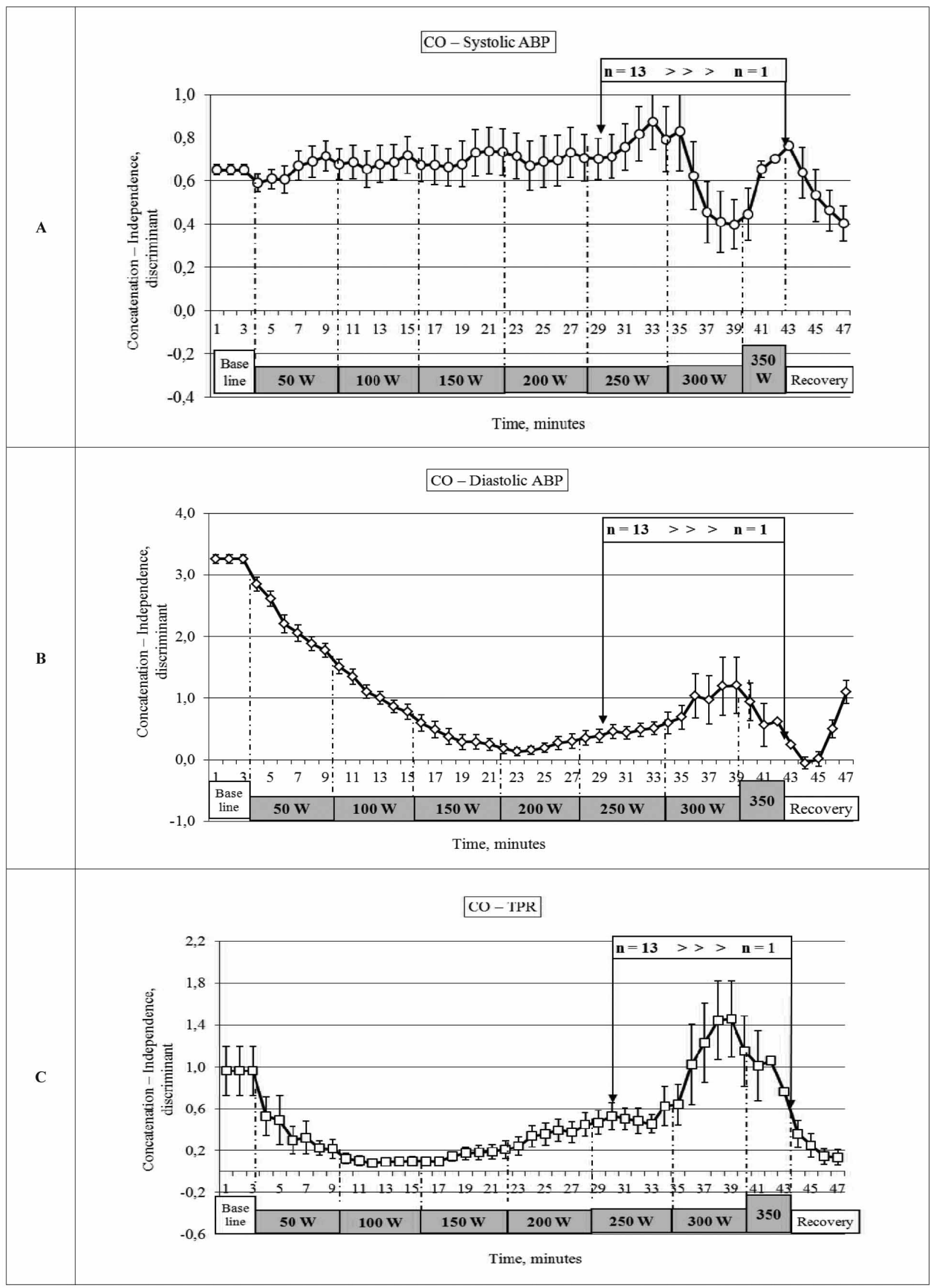

Figure 4. Dynamics of concatenation between cardiac output (CO) and cardiovascular indices changes during incremental exercise stress Note. TPR - total peripheral resistance, $>>>$ - decreasing numbers of participants were able to perform the workload. 
The main finding of this study was that the regular and everlasting changes of concatenation between registered indices started at onset of exercising. This type of changes was observed during some stages of workload, and when reaching some functional state (fatigue) the increase or decrease of concatenation changed in the opposite direction. This means that the concatenation between the changes in cardiac performance and behaviour of peripheral vasculature increase at onset of exercising and the decrease or loss of the concatenation leads to inability to continue exercising.

The other important finding in this study was that peripheral changes, i. e. decrease of diastolic ABP has an increasingly important role for muscular blood flow under conditions of increasing fatigue. In some studies (Buliuolis et al., 2003; Poskaitis et al., 2007) it was shown that relatively steady state could be observed during the first stages of stepwise incremental increase of exercising intensity while the duration of exercising at the each step of exercising was 6 minutes.

We used the method based on matrix theory proposed by Lithuanian scientists (Vainoras et al.,
2008; Bikulčienè et al., 2009) to assess the features of the dynamics of concatenation of some important cardiovascular indices. The results obtained during the study allowed to distinguish some peculiarities in the dynamics of cardiovascular parameters under increasing fatigue and it seems that application of this methodology are promising.

\section{CONCLUSIONS AND PERSPECTIVES}

1. The increase of cardiac output during the graded exercise stress has the same tendency of stepwise increase with each higher stage of workout, and the changes of systolic and diastolic blood pressure indices with accumulation of fatigue could be characterized as linear type dependent on the time of exercising.

2. The importance of peripheral factors, i. e. decrease of diastolic blood pressure, the reduction of total peripheral vascular resistance play an increasingly significant role for cardiac output during continuous exercising. The concatenations between the changes of these indices and cardiac output increase and in the case of high-grade fatigue concatenations begin to decline.

\section{REFERENCES}

Batzel, J. J., Bachar, M. (2010). Modelling the cardiovascular-respiratory control system: data, model analysis, and parameter estimation. Acta Biotheoretica, 58 (4), 369-580.

Berškienè, K. (2009). Elektrokardiografiniu signalu parametru dinaminiu sasaju analize: daktaro disertacija. Kaunas: KTU.

Bikulčienė, L., Navickas, Z., Vainoras, A., Poderys, J., Ruseckas, R. (2009). Matrix Analysis of Human Physiologic Data. Proceedings of International Conference on Information Technology Interfaces (pp. 41-46). University of Zagreb.

Buliuolis, A., Trinkūnas, E., Snarskaitè, R., Poderys, J. (2003). Didelio meistriškumo sportininkų ir nesportuojančių asmenu širdies ir kraujagyslių sistemos funkcinès būklès kaita atliekant aerobinius ir anaerobinius krūvius. Sporto mokslas, 1 (31), 56-61.

Davies, J., Grinfeld, M., Steven, D. (2010). Webb Introduction to the Special Issue. Theory in Biosciences. Springer-Verlag.

Demongeot, J., Françoise, J. P., Nerini, D. (2009). From biological and clinical experiments to mathematical models. Philosophical Transactions in the Royal Society A, 367, 4657-4663.
Goldberger, A. L., West, B. J. (1987). Fractals in physiology and medicine. Yale Journal of Biology and Medicine, 60 (5), 421-435.

Goldberger, A. L., Rigney, D. R., Mietus, J., Antman, E. M., Greenwald, S. (1988). Nonlinear dynamics in sudden cardiac death syndrome: Heart rate oscillations and bifurcations. Experientia, 1, 44 (11-12), 983-987.

Kubicek, W. G., Karnegis, J., N., Patterson, R., P., Witsoe, D. A., Matson, R. H. (1966). Development and evaluation of an impedance cardiac output system. Aerospace Medicine, 37, 1208-1212.

Latash, M. L., Mindy, F., Levin, Scholz, J. P., Schöner, G. (2010). Motor control theories and their applications. Medicina (Kaunas), 46 (6), 382-392.

Poderys, J., Venskaitytė, E., Poderienė, K., Buliuolis, A., Vainoras A. (2010). Functional state assessment on the dynamics of interparametric concatenations during exercise tests. Medicina (Kaunas), 46 (6), 429-434.

Poskaitis, V., Miseckaite, B., Venskaityte, E., Poderys, J., Vainoras, A. (2007). Characteristics of changes in oxygen saturation in muscular tissue and ischemic episodes in cardiac muscle during the bicycle ergometry [Article in Lithuanian]. Medicina (Kaunas), 43 (5), 385-389. 
Pukènas, K., Poderys, J., Gulbinas, R. (2012). Measuring the Complexity of a Physiological Time Series: A review. Ugdymas. Kūno kultūra. Sportas, 1, 48-54.

Pushkar', I. T., Bol'shov, V. M., Elizarova, N. A., Kukharchuk, V. V., Tsvetkov, A. A. (1977). Determination of cardiac output by the method of tetrapolar chest rheography and evaluation of its metrological possibilities (in Russian). Kardiologiia, 17, 85-90.

Saltin, B. (2007). Exercise hyperaemia: Magnitude and aspects on regulation in humans. Journal of Physiology, 15, 583 (Pt 3), 819-823.
Torrents, C., Balagué, N. (2006). Dynamic systems theory and sports training. Extrapolation, V, 60 (1), 72-83.

Vainoras, A., Navickas, Z., Poderys, J., Berskiene, K., Bikulciene L. (2008). ECG Signal for Assessment of Interpersonal or Inter Parameter Influences: the 2nd International Scientific Conference "Current Issues and New Ideas in Sport Science" [Electronic resource]. Kaunas.

\title{
IŠTVERMĘ LAVINANČIŲ ASMENŲ MINUTINIO KRAUJO TŪRIO IR ARTERINIO KRAUJO SPAUDIMO RODIKLIŲ DINAMINĖS SĄSAJOS ATLIEKANT PAKOPOMIS DIDINAMĄ KRŪVI
}

\author{
Vilma Papievienė, Eugenijus Trinkūnas, Alfonsas Buliuolis, \\ Albinas Grūnovas, Jonas Poderys \\ Lietuvos sporto universitetas, Kaunas, Lietuva
}

\begin{abstract}
SANTRAUKA
Tyrimo pagrindimas ir hipotezė. Ligšiol neišsisaiškinti visi galimi fiziologiniai mechanizmai, lemiantys raumenų kraujotakos kaitos ypatybes ilgos trukmės fizinių krūviu metu. Kita vertus, labai svarbus pasirenkamų analizès metodų informatyvumas, nes daugelis fiziologinių rodiklių negali būti tiesiogiai pamatuojami.

Tikslas - nustatyti dinaminių sąsajų kaitos ypatybes tarp centrinių ir periferinių kraujotakos rodiklių didejjančio nuovargio sąlygomis.

Metodai. Treniruoti ištvermès bèikai atliko pakopomis kas šešias minutes po $50 \mathrm{~W}$ didinamą krūvi veloergometru iki negalejjimo tęsti ji. Dinaminè sąsaja tarp minutinio kraujo tūrio ir kitu kraujotakos rodikliu (sistolinio bei diastolinio kraujo spaudimo ir bendrojo periferinio pasipriešinimo) buvo vertinami pasinaudojant Lietuvos mokslininkų pasiūlyta metodika, kuri grindžiama matricinės analizės teorija.

Rezultatai. Atliekant pakopomis didinamą krūvị minutinio kraujo tūrio reikšmès taip pat padidejja su kiekviena didesnio krūvio pakopa, tačiau sistolinio ir diastolinio AKS didejjimas kaupiantis nuovargiui gali būti nusakomas tiesine priklausomybe su atlikto krūvio laiku. Pradèjus ir tęsiant fizini krūvị, dinaminè sąsaja tarp minutinio kraujo tūrio ir periferinių kraujotakos rodiklių sustiprèja, tačiau prieš darbo pabaigą prasidedantị reikšmingą sąsajos mažèjimą lydi atsisakymas tęsti fizinį krūvị.

Aptarimas ir išvados. Didejjant nuovargiui, minutinio kraujo tūrio didèjimą vis labiau lemia periferiniai veiksniai: diastolinio kraujo spaudimo mažejimas, rodantis kraujagyslių vazodilatacijos lemiamą bendrojo periferinio pasipriešinimo mažejimą. Šių rodiklių dinaminès sąsajos su minutiniu kraujo kiekiu stiprèja, o atsiradus dideliam nuovargiui jos pradeda silpnèti.
\end{abstract}

Raktažodžiai: minutinis kraujo tūris, bendrasis periferinis pasipriešinimas, dinaminès sąsajos.

Gauta 2013 m. sausio 26 d.

Received on January 26, 2013

Priimta $2013 \mathrm{~m}$. kovo $8 \mathrm{~d}$.

Accepted on March 8 d., 2013
Corresponding author Vilma Papievienè

Lithuanian Sports University

Aušros str. 42, LT-44221 Kaunas

Lithuania

Tel +370302674

E-mail vilma.papieviene@1su.1t 